\title{
METHODS OF CELLULAR CONCRETE PRODUCTION USING FLY ASH
}

\author{
${ }^{1}$ Sasovsky T.A., Ph.D., \\ tarik_work777@ukr.net, ORCID: 0000-0002-7344-7968 \\ ${ }^{1}$ Chorna I.V., Ph.D., \\ slipikshop@gmail.com, ORCID: 0000-0002-7106-6766 \\ ${ }^{1}$ Shalay S.V., Ph.D., \\ sergijsalov07@gmail.com, ORCID: 0000-0002-5196-1747 \\ ${ }^{1}$ Lysiak O.M., \\ oxana2016free@gmail.com, ORCID: 0000-0001-9564-3188 \\ ${ }^{1}$ Separated structural subdivision "Rivne Professional College of \\ National University of Life and Environmental Sciences of Ukraine" \\ 44, Kopernika St., Rivne, 33001, Ukraine
}

\begin{abstract}
An analysis of modern capital construction state shows that the material and technical base of the construction industry does not allow the production of effective building materials and products in the required quantity without due consideration of the economic burden on the environment, and now significant financial costs are required to restore the ecological balance of the natural zone. Power plant fly ash is a man-made raw material for many industries, which is utilized up to $92 \%$ in dry form and is of practical interest in the production of effective thermal insulation building materials and products as a filler and an aggregate.

In view of the instability of the chemical and mineralogical composition, the content of raw fuel, as well as the pozzolanic activity, the study of the profitability of the production of pozzolanic cements and concretes based on them was carried out, with an increase in sulfate resistance, corrosion resistance of the aggregate while preventing thermal cracking. The expediency of autoclaved gas-ash-slag concretes production with the use of cement with high content of highly basic minerals - alite and tricalcium aluminate is proved. The technology of obtaining ash-alkaline cellular concrete using ashremoval and alkaline component is given. The economic efficiency of cellular ash-containing concretes is justified by the replacement of sand with ash, a 1.2-1.5-fold reduction in lime consumption compared to lime-sand concrete and a reduction of approximately 2 times the capital costs for extraction and processing of raw materials. Comparative physical and mechanical parameters of autoclave and nonautoclave aerated concrete products are given. The process of manufacturing products by vibrovacuuming and vibratory compaction of ash concrete is presented. The strength data of vacuum concrete are given, which are 30-40\% higher than that of vibro- compacted concrete from a rigid mixture. The investigated value of shrinkage as a result of the water-reducing effect of ash, provides a decrease in the water-cement ratio of concrete. Autoclaved and non-autoclaved aerated concrete can compete with such an effective thermal insulation material as mineral wool. They are more effective materials for low-rise and frame housing construction than traditional brick and concrete.
\end{abstract}

Keywords: fly ash, cellular concrete, vibration swelling, autoclaved and non-autoclaved concrete, silica component, thermal crack formation, pore former, vibration vacuuming, vacuum ash concrete, aerated ash concrete.

Introduction. The production of heat-insulating concretes with high performance properties by modification with complex fine-grained organical -mineral additives, with the simultaneous use of industrial waste as a man-made raw material, is becoming increasingly important due to the significant rise in energy prices.

Up to $50 \%$ of the energy saving reserve in the housing stock is related to the thermal insulation of the enclosing structures of residential buildings. The main losses of thermal energy fall on the walls and amount to more than $20 \%$. It should also be noted that the annual heat 
consumption in the houses of the residential sector is up to 41 million $\mathrm{kJ}$, while in other European countries this figure is several times lower.

Therefore, one of the promising areas of ash and slag waste disposal is the production of porous aggregates for lightweight concrete. Ash is also used as a filler for the production of rolled roofing materials. The most widely used is ash, which is released to consumers for use as an additive to cement, expanded clay, clay and silicate bricks, and other purposes. Requirements for ash as a component of cement are given in DSTU B V.2.7-128:2006 and are mainly limited to restrictions on losses during calcination $(<3 \%)$.

Fly ash is a fine material consisting mainly of particles with a size of $0.005-0.1 \mathrm{~mm}$. Its chemical and mineralogical composition corresponds to the composition of the mineral part of the fuel which is burned. During the combustion of coal, ash is a calcined clay substance with the inclusion of dispersed particles of quartz sand. At firing of a mineral part of fuel the clay substance is dehydrated and low-basic aluminates and silicates of calcium are formed.

Analysis of recent researches and publications. The presence of amorphous silicon oxide and alumina with calcium hydroxide formed during hydration of cement in the ash causes the formation of calcium silicate hydrate phase (CSH-phase). Additionally, formed calcium hydrosilicates help to increase the durability of concrete. Studies have shown the feasibility of using ash as a mineral additive and microfiller in the manufacture of concrete $[1,2]$ due to changes in the basic properties of concrete mixture and concrete based on composite binders [3]:

- reduction of water separation and stratification of concrete mixture;

- increasing the cohesion of the concrete mixture;

- reduction of shrinkage as a result of water-reducing effect of ash that provides decrease in the water-cement ratio of concrete;

- reduction of thermal cracking as a result of lower heat dissipation (with replacement of up to $50 \%$ of cement by fly ash, the temperature gradient between the center and the surface of the array does not exceed $25 \%$ );

- increasing the water resistance and durability of concrete (reducing water consumption and modification of hydration products).

Purpose and objectives: to investigate effective ways of using ash and slag waste in the production of building materials, taking into account the instability of chemical and mineralogical composition, the content of unburned fuel, as well as pozzolanic activity. The tasks require a more detailed study of the profitability of the production of pozzolanic cements and concretes based on them, with increased sulfate resistance, corrosion resistance of the filler and the prevention of thermal cracking [4]. Due to the spherical shape of the ash grains, the additive has a property called "ball-bearing effect", which improves the sliding of cement and sand on the glassy surface of ash particles, similar to emulsified air bubbles when using air-repellent additives to plasticize the concrete mixture. Slowing down the hydration of the cement binder due to the introduction of fly ash causes the growth of newly formed crystals, which contributes to chemical compaction and reduction of pores in hardened concrete. According to modern ideas, the strength of cements and concretes with the addition of ash depends on the thickness of the surface layer of the ash particle disturbed by chemical processes [5].

Materials and methods of research. Low-calcium ash of Ladyzhynska TPP (DSTU B V.2.7-205:2009) ground to a specific surface area of $8000 \mathrm{~cm}^{2} / \mathrm{g}$ according to Blaine was chosen as raw material, and sodium carbonate technical (GOST 5100) was used as an alkaline component. To activate the system, Portland cement I-500 manufactured by PJSC "Volyn-cement" with a specific Blaine surface area of $3800 \mathrm{~cm}^{2} / \mathrm{g}$ and granular blast furnace slag of PJSC Ilyich Iron and Steel Works of Mariupol ground to a specific surface according to Blaine $4500 \mathrm{~cm}^{2} / \mathrm{g}$. To improve the technological characteristics, a plasticizing additive, an alkaline component - liquid glass and caustic soda melt were used. The chemical composition of the raw materials is shown in table 1 . 
Table 1 - Chemical composition of raw materials, \%

\begin{tabular}{|l|c|c|c|c|c|c|c|c|c|}
\hline \multicolumn{1}{|c|}{ Material } & $\mathrm{SiO}_{2}$ & $\mathrm{Al}_{2} \mathrm{O}_{3}$ & $\mathrm{Fe}_{2} \mathrm{O}_{3}$ & $\mathrm{CaO}$ & $\mathrm{MgO}$ & $\mathrm{SO}_{3}$ & $\mathrm{Na}_{2} \mathrm{O}$ & $\mathrm{K}_{2} \mathrm{O}$ & $\begin{array}{c}\text { losses } \\
\text { during } \\
\text { calcination } \\
\text { l.d.c }\end{array}$ \\
\hline Ash & 51.08 & 24.8 & 13.67 & 3.12 & 1.83 & 0.08 & 0.60 & 1.90 & 1.50 \\
\hline CEM I 42.5 & 23.4 & 5.17 & 4.12 & 64.13 & 0.88 & 0.55 & 0.41 & 0.33 & 0.20 \\
\hline Slag & 40.0 & 5.91 & 0.32 & 46.98 & 5.87 & 1.62 & - & - & - \\
\hline
\end{tabular}

Selection of the composition and production of samples of alkaline concrete was performed according to DSTU B V.2.7-69-98 and DSTU B V.2.7-96-2000. Requirements for ash as a component of cement are given in DSTU B V.2.7-128:2006.

Significant practical experience in the application of fly ash in concrete has been accumulated in hydraulic engineering. Currently, the efficiency of replacing 25-30\% of Portland cement with fly ash for concrete of the inner zones of massive hydraulic structures and 15-20\% for concrete of underwater parts of structures has been proven. In some cases, the expediency of increasing the content in the hydraulic concrete of fly ash to $50-60 \%$ by weight of cement is justified. When replacing with ash up to $40 \%$ of cement during their joint grinding, the strength of concrete after 28 days is close, and after 60 days is almost equal to the strength of concrete without additives.

Despite the reduction of the cement content due to the addition of ash, after 20 hours of exposure in the air environment at a temperature of $20^{\circ} \mathrm{C}$ we managed to achieve the same compressive strength. After 7 days ( 1 day of exposure in air and 6 days of exposure in water at $20^{\circ} \mathrm{C}$ ) the strength of the mixture with ash content was approximately $2 \mathrm{~N} / \mathrm{mm}^{2}$ higher than the standard mixture. After 28 days (final exposure in the air at $20^{\circ} \mathrm{C}$ ) the strength of the standard mixture was more than $3 \mathrm{~N} / \mathrm{mm}^{2}$ lower than the mixture with ash content $\left(62.9 \mathrm{~N} / \mathrm{mm}^{2}\right.$ and $\left.66.3 \mathrm{~N} / \mathrm{mm}^{2}\right)$.

The results of experimental laboratory studies conducted to optimize the composition of the concrete mixture for the production of reinforced concrete structures using ash, confirm the feasibility of introducing a plasticizing additive due to the presence of ettringite-like tumors that reduce the strength of concrete.

The technology of obtaining alkaline cellular concrete with the use of fly ash and alkaline component (liquid glass and caustic soda melt) for thermal insulation in industrial and civil buildings has been developed. Cement-based cellular concretes are more stable than lime-based aerated concretes. The ash used for aerated concrete due to the content of unburned fuel and the instability of the chemical composition are technological requirements for the content of vitreous and molten hours of brown coal - not more than 3\%, stone - not more than 5\%, specific surface $3000 \ldots 5000 \mathrm{~cm}^{2} / \mathrm{g}$, the value of swelling in water - not more than $5 \%$. The negative features include their ability to high sorption moisture, due to the high microporosity of the ash, as well as increased sensitivity to cyclic moisture and drying than dense concrete. In the manufacture of autoclaved aerated concrete, the use of low-level cements in particular slag Portland cement and pozzolanic Portland cement is possible. So as autoclaved aerated concrete does not protect steel reinforcement from corrosion, there is a need to take special measures to protect it in structures, and the surface of reinforced concrete is protected from aggressive atmospheric influences [6].

The most suitable for the production of aerated ash slag concrete products is a complex vibration technology (vibration swelling), which allows, due to the liquefaction of the mixture while vibrating in the process of mixing and molding, to reduce the amount of mixing water and shrinkage deformation by $25-30 \%$, increase concrete homogeneity and strength increases by $15-25 \%$. The pore-forming agent is an aqueous suspension of aluminum powder, for emulsification of which sulfanol, household soap is used; the rate of swelling of the mixture is regulated by adding sodium hydroxide; solidification time - with the addition of lime. The consumption of aluminum powder

Bulletin of Odessa State Academy of Civil Engineering and Architecture, 2021, no. 82, page 114-122 
per $1 \mathrm{~m}^{3}$ of cellular concrete depends on its average density: at values of average density 350, 500, $600,700,800 \mathrm{~kg} / \mathrm{m}^{3}$ the consumption of aluminum powder is $690,535,470,360$ and $300 \mathrm{~g}$, respectively. To reduce the shelf life of products and autoclave processing by 1.5-2 times, additives of monoethanolamine, triethanolamine, trisodium phosphate are introduced, and it intensifies the process of structure formation in the initial terms. The strength of aerated concrete directly depends on its average density, as well as the nature of the porosity, which, in turn, depends not only on the composition of the mixture, but on the heat treatment conditions.

For the production of autoclaved gas-ash-slag concrete, it is desirable to use cement with increased content of highly basic minerals - alite and tricalcium aluminate.

The main parameters of the composition of aerated concrete are the ratio of siliceous component to the binder $\mathrm{S}$ and the water-solid ratio W/S, which provides a given fluidity of the mixture. Oriented values of these values in determining the composition of concrete are given in Table 2, compiled from experimental data [7].

Table 2 - The ratio of silica component to binder in aerated concrete mixture

\begin{tabular}{|l|l|l|}
\hline \multirow{2}{*}{\multicolumn{1}{|c|}{ Binder }} & \multicolumn{2}{|c|}{ Indicator $\mathrm{S},(\%)$ by weight, for concrete } \\
\cline { 2 - 3 } & \multicolumn{1}{|c|}{ autoclave } & $\begin{array}{c}\text { non-autoclaved on the ash- } \\
\text { removal }\end{array}$ \\
\hline Cement and cement-lime & $0.75 ; 1.0 ; 1.25 ; 1.5 ; 1.75 ; 2.0$ & $0.75 ; 1.0 ; 1.25$ \\
\hline Lime-slag & $0.6 ; 0.8 ; 1.0$ & $0.6 ; 0.8 ; 1.0$ \\
\hline Slag-alkaline & $0.1 ; 0.15 ; 0.2$ & - \\
\hline
\end{tabular}

The composition of aerated concrete is determined taking into account the ratio of siliceous component to the binder in the mixture (Table 2), determine the water-solid ratio W/S, which provides a given fluidity of the mortar mixture (Table 3) taking into account the temperature of the mixture at the time of its unloading from the molds (Table 4), determine the amount of porous agent per batch (adjusted by the coefficient of use of porous agent and bound water in the material), set the consumption of dry components, additives and water for test batch, taking into account not only the properties of cellular concrete, but also the conditions of formation - swelling temperature and solidification time.

Table 3 - Fluidity of cellular concrete mixture

\begin{tabular}{|c|c|c|c|}
\hline \multirow{2}{*}{$\begin{array}{c}\text { Average density of } \\
\text { concrete, } \mathrm{kg} / \mathrm{M}^{3}\end{array}$} & \multicolumn{3}{|c|}{ Fluidity (flow diameter), $\mathrm{cm}$, mixture on the binder } \\
\hline & $\begin{array}{l}\text { Cement, lime-cement, slag- } \\
\text { alkaline }\end{array}$ & $\begin{array}{c}\text { Limestone, lime } \\
\text { slag }\end{array}$ & Highly basic, ash \\
\hline \multicolumn{4}{|c|}{ With casting technology } \\
\hline 300 & 38 & 30 & - \\
\hline 400 & 34 & 25 & 25 \\
\hline 500 & 30 & 23 & 23 \\
\hline 600 & 26 & 21 & 21 \\
\hline 700 & 22 & 19 & 20 \\
\hline 800 & 18 & 17 & 18 \\
\hline \multicolumn{4}{|c|}{ With vibration technology } \\
\hline 500 & 15 & - & - \\
\hline 600 & 13 & - & - \\
\hline 700 & 11 & - & - \\
\hline 800 & 9 & - & - \\
\hline
\end{tabular}


The use of cellular concrete with a low water-cement ratio for the production of reinforced concrete structures can lead to incomplete hydration of cement, which remains in the hardened concrete and the share of which increases with decreasing water-cement ratio.

Under certain conditions, the consequence of incomplete hydration of cement can be a violation of the process of structure formation, which, in turn, leads to a decrease in compressive strength. The optimal amount of ash along with the reduction of unhydrated cement in concrete contributes to the achievement of both high early strength and strength at the design age.

Table 4 - Temperature of cellular concrete mixture

\begin{tabular}{|l|c|c|}
\hline \multirow{2}{*}{\multicolumn{1}{|c|}{ Cellular concrete and binder }} & \multicolumn{2}{|c|}{ Mixture temperature, ${ }^{0} \mathrm{C}$} \\
\cline { 2 - 3 } & Casting technology & $\begin{array}{c}\text { During vibration } \\
\text { molding }\end{array}$ \\
\hline Aerated concrete: & 45 & 45 \\
on cement & 35 & 40 \\
on lime-cement binder & 40 & 45 \\
on lime-slag binder & 30 & 40 \\
\hline Gas silicate & & \\
\hline Foam concrete: & 25 & - \\
on cement & 15 & - \\
on slag-alkaline binder & & \\
\hline
\end{tabular}

Results of the research. The main obstacle to the use of developed materials is the instability of the chemical composition of fuel ashes, which necessitates constant control over the quality of input products and the possibility of rapid adjustment of cement and concrete production technology based on it [8]. Ash-based alkaline cements show less sensitivity to adverse hardening conditions compared to blast-furnace (slag) cement III/A-400, which makes them a promising system for use in monolithic construction. When using alkaline pozzolanic cement ("fly ash Portland cement - alkaline component - surfactant") provides the highest strength of concrete at a variable temperature during the month $\left(\mathrm{t}=5^{\circ} \mathrm{C}\right.$ to $\left.20^{\circ} \mathrm{C}\right)$, and the use of alkaline composite cement ("fly ash - ground granulated blast furnace slag - Portland cement - alkaline component surfactant") is optimal for concreting at elevated temperatures $\left(\mathrm{t}=20^{\circ} \mathrm{C}\right.$ to $\left.30^{\circ} \mathrm{C}\right)[9]$.

The economic efficiency of cellular ash-containing concretes is justified by the replacement of sand with ash, a 1.2-1.5 fold reduction in lime consumption compared to lime-sand concrete and a reduction of approximately 2 times the capital costs for extraction and processing of raw materials. The method of production of small aerated concrete products is to grind lump limestone and compatible grinding it with ash in a ball mill in the ratio of lime: ash $=5: 1$. The fineness of grinding lime should be $5000 \mathrm{~cm}^{2} / \mathrm{g}$. Aluminum powder or paste is supplied in factory packaging for the preparation of aluminum suspension in the shop of aerated ash slag concrete. Dosing of dry components takes place by automatic weight batchers; sludge, water and suspension - volumetric in the form of measuring tanks with taps. The aerated ash slag concrete mixture is prepared in a mixer with the volume of $1.8 \mathrm{~m}^{3}$. The sequence of components loading is as follows: sludge of cutting waste; water; fly ash; Portland cement; ash-lime binder, water-aluminum suspension. Forming is by casting, percussion or vibrotechnology. The edge is removed with a conical cutter, longitudinalhorizontal cutting of the array, cross-section on blocks is carried out by the cutting equipment. The cut array is transported on the pallet to the post of autoclave trolleys or steaming chamber. Cutting waste is returned to the production process or after heat-moisture treatment (HMT) can be used as insulation of buildings and structures ceilings. After autoclaving or steaming, the finished product enters the warehouse. 
Frost resistance depends on the characteristics of the pore structure of concrete. Uniform pore distribution and reduction of capillary porosity increase frost resistance. Cement-based concretes are more frost-resistant than lime. To reduce water absorption and increase frost resistance in the cellular structure, the condition of closed pores must be fulfilled. This is facilitated by vibration technology with the possibility of obtaining a homogeneous material, with destroyed large pores that reduce frost resistance. The thermal conductivity of aerated concretes depends mainly on density and humidity and is $0.065-0.07 \mathrm{~W} /\left(\mathrm{m} \cdot{ }^{\circ} \mathrm{C}\right)$ for $\rho_{0} \geq 200 \mathrm{~kg} / \mathrm{m}^{3} ; \lambda=0.21-0.26 \mathrm{~W} /\left(\mathrm{m} \cdot{ }^{\circ} \mathrm{C}\right)$ for $\rho_{0}=1000 \mathrm{~kg} / \mathrm{m}^{3}$. Cellular aerated concrete is characterized by high sound insulation properties [10].

Comparative physical and mechanical properties of autoclaved and non-autoclaved aerated concrete products are presented in Table. 5 .

Table 5 - Comparative physical and mechanical properties of aerated concretes

\begin{tabular}{|l|c|c|}
\hline \multirow{2}{*}{\multicolumn{1}{|c|}{ Parameters }} & \multicolumn{2}{c|}{ Aerated concrete } \\
\cline { 2 - 3 } & non-autoclaved & autoclaved \\
\hline Compressive strength class & B2.5/M35 & B2.5/M35 \\
\hline Medium density mark & D750 & D600 \\
\hline Frost resistance mark, not less & F25 & F25 \\
\hline $\begin{array}{l}\text { Thermal conductivity coefficient, } \\
\left.\text { W/(m }{ }^{\circ} \mathrm{C}\right) \text {, not more }\end{array}$ & 0.32 & 0.14 \\
\hline Vacuum humidity, \% by weight, not more & 35 & 35 \\
\hline Weight of one block, kg & 24 & 18 \\
\hline Dimensions of the floor slab, mm & - & $4200 \times 1200 \times 240$ \\
& $200 \times 300 \times 400$ & $188 \times 300 \times 588$ \\
\hline Block sizes, mm & &
\end{tabular}

For the manufacture of products by vibration evacuation, the process of obtaining a concrete mixture is to prepare ash sludge in a rotary mixer with a water-ash ratio of 0.5 (taking into account the variable humidity of the ash from the dump), cement dosage and, if necessary, additional water, bringing the concrete mix to the required plasticity. This method of production of reinforced concrete on the basis of such a mixture of vibration evacuation allows to remove residual mixing water in the molding process. The result is compacted ash concrete with high structural strength, which allows for rapid stripping. From the concrete mixture 1:4 (cement: ash) with a mobility from $\mathrm{OK}=2-3 \mathrm{~cm}$ to $\mathrm{OK}=12-14 \mathrm{~cm}$ samples were formed by vibro-vacuuming and for comparison - by vibration, lasting 60-65 s. [11]. The obtained research results are given in Table 6. From the given data it is seen that the rational mobility of the concrete mixture for vacuuming when reaching the maximum strength of the vacuumed concrete is $\mathrm{OK}=8-10 \mathrm{~cm}$. It should be noted that the strength of vacuum concrete is $30-40 \%$ higher than that of vibro-compacted concrete from a rigid mixture.

Table 6 - Average density and strength of vibro-compacted and vibro-vacuumed ash concretes

\begin{tabular}{|c|c|c|c|c|c|c|c|}
\hline Type c.m. & \multicolumn{2}{|c|}{ Vibro-compacted concrete } & \multicolumn{4}{|c|}{ Vibro-vacuumed concrete } \\
\hline $\begin{array}{c}\text { Mobility } \\
\text { of the } \\
\text { mixture, } \\
\text { OK (cm): }\end{array}$ & V/C & $\begin{array}{c}\text { Average } \\
\text { density, } \\
\text { Kg/m }\end{array}$ & $\begin{array}{c}\text { Strength, } \\
\mathrm{MPa}\end{array}$ & $\begin{array}{c}\text { The } \\
\text { amount of } \\
\text { water } \\
\text { removed, } \\
1 / \mathrm{m}^{3}\end{array}$ & $\mathrm{~V} / \mathrm{C}$ & $\begin{array}{c}\text { Average } \\
\text { density, } \\
\mathrm{Kg} / \mathrm{m}^{3}\end{array}$ & $\begin{array}{c}\text { Strength, } \\
\mathrm{MPa}\end{array}$ \\
\hline $2 \ldots 3$ & 1.93 & 1586 & 6.2 & 95 & 1.53 & 1620 & 11.9 \\
\hline $5 \ldots 6$ & 2.12 & 1577 & 4.9 & 112 & 1.58 & 1631 & 13.1 \\
\hline $8 \ldots 9$ & 2.31 & 1569 & 2.9 & 126 & 1.62 & 1642 & 14.4 \\
\hline $11 \ldots 12$ & 2.41 & 1560 & - & 133 & 1.69 & 1635 & 14.2 \\
\hline $13 \ldots 14$ & 2.52 & 1553 & - & 136 & 1.72 & 1628 & 13.9 \\
\hline
\end{tabular}


Conclusions. From the above mentioned methods of production of thermal insulation building materials using fly ash and water removal ash follows the justification of the prospects of involvement in the production of aerated concrete of this dispersed raw waste of industry, the volume of which will continue to grow due to reduced natural gas exports and increased weight in the energy sector of Ukraine. Autoclaved and non-autoclaved aerated concrete using industrial waste, cementless or lowcement (not more than $100 \mathrm{~kg} / \mathrm{m}^{3}$ ) can compete with such an effective thermal insulation material as mineral wool, that is much more effective material for low-rise and frame housing than brick.

\section{References}

[1] L.J. Dvorkin, A.V. Myronenko, Budivelni materialy ta vyroby iz zastosovuvannyam promyslovyh vidxodiv: Navch. Posib. Rivne : NUVGP, 2019.

[2] A. Ahmad, F. Farooq, P. Niewiadomski, K. Ostrowski, A. Akbar, F. Aslam, R. Alyousef, "Prediction of Compressive Strength of Fly Ash Based Concrete Using Individual and Ensemble Algorithm", Materials (Basel), 14(4), 794, 2021 [Online]. Available: http://doi.org/10.3390/ma14040794.

[3] M. Fuzail Hashmi, Shariq A. Baqi, "An investigation into age-dependent strength, elastic modulus and deflection of low calcium fly ash concrete for sustainable construction", Construction and Building Materials, vol. 283, 122772, 2021. [Online]. Available: http://doi.org/10.1016/j.conbuildmat.2021.122772.

[4] V.M. Malhotra, Innovative Applications of Superplasticizers in Concrete - A Review. Mario Collepardi Symp. on Advances in Concrete Science and Technology: Proc. Ed. P. K. Mehta. E'Rome (Italy),1997. pp. 271-314.

[5] O.U. Kovalchuk, V.V. Grabovchak, M.O. Popovych, "Betony zagalnobudivelnogo pryznachennya na osnovi zololuzhnogo cementu", Visnyk Odeskoj derzhavnoyi akademiyi budivnycztva ta arxitektury, vol. 39, pp. 365, 2010.

[6] L.O. Shejnich, A.S. Pryjmachenko, "Modelyuvannya procesu koroziyi vysokomicznyx betoniv u sulfatnomu seredovyschi", Sxidno-Yevropejskyj zhurnal peredovyx texnologij, no. 2(6) (80), pp. 53-59, 2016.

[7] V.I. Gocz, Betony i budivelni rozchyny: Posibnyk. K.: KNUBA, 2003.

[8] V.P. Omelchuk, I.O. Aznauryan, O.Yu. Kovalchuk, "Zastosuvannya promyslovyx vidxodiv dlya vyrobnycztva novyx efektyvnyx cementiv i nizdryuvatyx betoniv na jix osnovi", Visnyk NTUU «KPI». Seriya «Girnycztvo», vol. 18, pp. 48-52, 2009.

[9] P.V. Kryvenko, V.V. Grabovchak, "Texnologichni osoblyvosti otrymannya betoniv na osnovi luzhnyx zolovmisnyx cementiv", Stroytelnue materyalu i izdeliya, no. 4, pp. 2427. 2013.

[10]P.P Deryabin, Teoriya y texnologyya stroytelnux yzdelyj yz yacheystux betonov: monografyya. Omsk: SybADY, 2015. [Online]. Available: http://bek.sibadi.org/fulltext/ed2206.pdf.

[11]N.A. Storozhuk, T.M. Pavlenko, A.R. Abbasova, "Osoblyvosti zoly teplovyx elektrostancij yak zapovnyuvacha dlya betoniv", Nauka ta progres transportu. Visnyk Dnipropetrovskogo nacionalnogo universytetu zaliznychnogo transportu, vol. no. 5 (71), pp. 149-157, 2017. 


\title{
СПОСОБИ ВИРОБНИЦТВА НІЗДРЮВАТОГО БЕТОНУ 3 ВИКОРИСТАННЯМ ЗОЛИ-ВИНОСУ
}

\author{
${ }^{1}$ Сасовський Т.А., к.т.н., \\ tarik_work777@ukr.net, ORCID: 0000-0002-7344-7968 \\ ${ }^{1}$ Чорна I.B., к.T.H., \\ slipikshop@gmail.com, ORCID: 0000-0002-7106-6766 \\ ${ }^{1}$ Шалай С.В., к.с.-Г.н., \\ sergijsalov07@gmail.com, ORCID: 0000-0002-5196-1747 \\ ${ }^{1}$ Лисяк О.М., \\ oxana2016free@gmail.com, ORCID: 0000-0001-9564-3188 \\ ${ }^{1}$ Відокремлений структурний підрозділ «Рівненський фаховий коледж \\ Національного університету біоресурсів і природокористування Украӥни» \\ вул. Коперніка 44, м. Рівне, 33001, Україна
}

\begin{abstract}
Анотація. Аналіз стану сучасного капітального будівництва показує, що матеріальнотехнічна база будівництва та будівельної індустрії не дозволяє виробляти в потрібній кількості ефективні будівельні матеріали та вироби без належного врахування економічних навантажень на навколишнє середовище і тепер необхідні значні фінансові витрати на відновлення екологічної рівноваги природної зони. Зола-виносу електростанцій $\epsilon$ техногенною сировиною для багатьох галузей промисловості, яка утилізується до $92 \%$ в сухому вигляді i представляє практичний інтерес у виробництві ефективних теплоізоляційних будівельних матеріалів та виробів в якості наповнювача і заповнювача.

Зважаючи на нестабільність хімічного і мінералогічного складу, змісту невипаленого палива, а також пуцоланової активності в роботі проведено дослідження рентабельності виробництва пуцоланових цементів та бетонів на їх основі, 3 підвищенням сульфатостійкості, корозійної стійкості заповнювача при запобіганні термічного тріщиноутворення. Доведена доцільність виробництва безавтоклавних газозолошлакового бетону із застосуванням цементу із підвищеним вмістом високоосновних мінералів - аліту і трикальцієвого алюмінату. Наведена технологія отримання зололужних ніздрюватих бетонів 3 використанням золи-виносу і лужного компоненту. Економічна ефективність ніздрюватих золовмісних бетонів обгрунтована заміною піску золою, зменшенням в 1,2-1,5 рази витрати вапна порівняно з вапняно-піщаним бетоном і скороченням приблизно в 2 рази капітальних витрат на добування і переробку вихідної сировини. Приведені порівняльні фізико-механічні показники автоклавних та неавтоклавних газозолобетонних виробів. Показано процес виготовлення виробів шляхом вібровакуумування та віброущільнення золообетону., Наведені дані міцності вакуумзолобетону, що $\epsilon$ на 30-40\% більшою, ніж міцність віброущільненого бетону 3 жорсткої суміші. Досліджене значення усадки в результаті водоредукуючого ефекту золи забезпечує зниження водоцементного співвідношення бетону.

Досліджене значення всідання в результаті водоредукуючого ефекту золи, що забезпечує зниження водоцементного співвідношення бетону. Автоклавні і неавтоклавні газобетони можуть конкурувати 3 таким ефективним теплоізоляційним матеріалом, як мінеральна вата. Вони є більш ефективними матеріалами для малоповерхового та каркасного будівництва житла, ніж традиційні цегла і бетон.
\end{abstract}

Ключові слова: зола-виносу, ніздрюватий бетон, автоклавний та неавтоклавний бетон, кремнеземистий компонент, термічне тріщиноутворення, пороутворювач, вібровакуумування, вакуумзолобетон, газозолобетон. 


\title{
СПОСОБЫ ПРОИЗВОДСТВА ЯЧЕИСТОГО БЕТОНА С ИСПОЛЬЗОВАНИЕМ ЗОЛЫ-УНОСА
}

\author{
${ }^{1}$ Сасовский Т.А., к.Т.н. \\ tarik_work777@ukr.net, ORCID: 0000-0002-7344-7968 \\ 'черная И.В., к.т.н., \\ slipikshop@gmail.com, ORCID: 0000-0002-7106-6766 \\ ${ }^{1}$ Шалай С.В., к.с.-Х.н., \\ sergijsalov07@gmail.com, ORCID: 0000-0002-5196-1747 \\ ${ }^{1}$ Лисяк О.Н., \\ oxana2016free@gmail.com, ORCID: 0000-0001-9564-3188 \\ ${ }^{1}$ Обособленное структурное подразделение «Ровенский профессиональный колледж \\ Национального университета биоресурсов и природопользования Украины» \\ ул. Коперника 44, г. Ровно, 33001, Украина
}

\begin{abstract}
Аннотация. Анализ состояния современного капитального строительства показывает, что материально-техническая база строительства и строительной индустрии не позволяет производить в нужном количестве эффективные строительные материалы и изделия без должного учёта экономических нагрузок на окружающую среду и теперь необходимы значительные финансовые затраты на восстановление экологического равновесия природной зоны. Зола-уноса электростанций является техногенной сырьем для многих отраслей промышленности, утилизируется до 92\% в сухом виде и представляет практический интерес в производстве эффективных теплоизоляционных строительных материалов и изделий в качестве наполнителя и заполнителя.
\end{abstract}

Ввиду нестабильности химического и минералогического состава, содержания необожженного топлива, а также пуццолановой активности в работе проведено исследование рентабельности производства пуццолановых цементов и бетонов на их основе, с повышением сульфатостойкости, коррозионной стойкости заполнителя при предотвращении термического трещинообразования. Доказана целесообразность производства безавтоклавного газозолошлакового бетона с применением цемента с повышенным содержанием высокоосновных минералов - алита и трехкальциевого алюмината. Приведенная технология получения золощелочных ячеистых бетонов с использованием золы-уноса и щелочного компонента. Экономическая эффективность ячеистых золоемких бетонов обоснована заменой песка золой, уменьшением в 1,2-1,5 раза расхода извести по сравнению с известково-песчаным бетоном и сокращением примерно в 2 раза капитальных затрат на добычу и переработку исходного сырья. Приведены сравнительные физико-механические показатели автоклавных и неавтоклавных газозолобетонных изделий. Показан процесс изготовления изделий путем вибровакуумирования и виброуплотнения золобетона. Приведенные данные прочности вакуумзолобетона, что на 30-40\% больше, чем в виброуплотненного бетона с жесткой смеси. Исследованное значение усадки в результате водоредуцирующего эффекта золы обеспечивает снижение водоцементного соотношения бетона. Автоклавные и неавтоклавные газобетоны могут конкурировать с таким эффективным теплоизоляционным материалом, как минеральная вата. Они являются более эффективными материалами для малоэтажного и каркасного строительства жилья, чем традиционные кирпич и бетон.

Ключевые слова: зола-уноса, ячеистый бетон, автоклавный и неавтоклавный бетон, кремнеземистый компонент, термическое трещинообразования, порообразователь, вибровакуумирование, вакуумзолобетон, газозолобетон.

Стаття надійшла до редакції 9.02.2021 